ISSN: 2224-0616

Int. J. Agril. Res. Innov. \& Tech. 2 (2): 15-24, December, 2012 Available online at http:// www.ijarit.webs.com

\title{
GROWTH AND YIELD PERFORMANCE OF SHINGI, Heteropneustes fossilis AND KOI, Anabas testudineus IN BANGLADESH UNDER SEMI-INTENSIVE CULTURE SYSTEMS
}

\author{
B. K. Chakraborty ${ }^{*}$ and N.N. Nur ${ }^{2}$
}

Received 4 October 2012, Revised 15 December 2012, Accepted 25 December 2012, Published online 31 December 2012

\begin{abstract}
Production potential of shingi, Heteropneustes fossilis and koi, Anabas testudineus in polyculture were assessed at a stocking density of $2,47,000$ and 3, 70,500 ha- ${ }^{-1}$, respectively in treatment $\mathrm{T}_{1}$ and $\mathrm{T}_{2}$. Monoculture of $\mathrm{H}$. fossilis and $\mathrm{A}$. testudineus was designed at a stocking density of $2,47,000$ ha $^{-1}$ in treatment $T_{3}$ and $T_{4}$, respectively. Culture period of shingi was 120 days and koi was 100 days in all treatments. All fingerlings were of the same age at stocking, with a mean weight of $2.54 \pm 0.08 \mathrm{~g}$ for shingi and $0.50 \pm 0.01 \mathrm{~g}$ for koi, respectively. Commercial fish feeds (30.0\% crude protein) supplied at the rate of 100 to $5 \%$ of total biomass twice daily. Fish production in treatment $\mathrm{T}_{1}, \mathrm{~T}_{2}, \mathrm{~T}_{3}$ and $\mathrm{T}_{4}$ were $18,803 \pm 111$, $12,388 \pm 115,10,042 \pm 5 \mathrm{~kg}^{2} \mathrm{a}^{-1}$ day ${ }^{120}$ and $22,176 \pm 7 \mathrm{~kg} \mathrm{ha}^{-1}$ day ${ }^{100}$, respectively. The feed conversion ratio $(\mathrm{FCR})$ was significantly $(\mathrm{P}<0.05)$ lower in $\mathrm{T}_{4}$ than that of the other three treatments. The net financial benefits incurred from treatment $T_{1}, T_{2}, T_{3}$ and $T_{4}$ were Bangladeshi Taka 17,65,769; 6,691; 15,83,990 and 16,29,409 BDT ha-1, respectively. The mean differences of gross yields and net benefits among different treatments were significant $(\mathrm{P}<0.05)$. The polyculture technology of shingi and koi, and monoculture technology of koi may help to meet the dietary needs and improve the socio-economic status of the people of Bangladesh.
\end{abstract}

Keywords: Growth, Yield Performance, Shingi, Koi

${ }^{1}$ Mathsya Bhabon, Department of Fisheries, Dhaka-1000, Bangladesh

${ }^{2}$ Programme Manager, NETZ, Dhaka, Bangladesh

*Corresponding author's email: bborty@gmail.com (B.K. Chakraborty)

\section{Introduction}

Polyculture or composite fish culture is the system in which fast growing compatible species with different feeding habits are grown in the same pond (Jhingran, 1975). Polyculture management technique is based on the relationship between fishes at different levels of the food chain and environment. The outcome of fish production from polyculture systems depends on the species combinations and their stocking densities. Polyculture is one of the major culture techniques that have been used traditionally in Bangladesh, where carp polyculture is practised in the farmer's ponds for rapid growth and maximum production. However, there is no information on polyculture practice of $\mathrm{H}$. fossilis (Heteropneustadae) and A. testudineus (Anabantidae) in Bangladesh. The local name of $\mathrm{H}$. fossilis and A. testudineus is shingi and koi (IUCN, 2000). So, this polyculture culture technology is a completely new one in South East Asia (Chakraborty and Mirza, 2008).

Heteropneustes fossilis (Bloch) is an indigenous stinging catfish of South-East-Asia, which is locally known as Shingi or Shing in different parts of Bangladesh. It is not only recognised for its excellent taste and market value but is also highly sought after for its nutritional and medicinal benefits. The species has high content of iron (226 mg $100 \mathrm{~g}^{-1}$ ) and fairly high content of calcium compared to many other freshwater fishes (Saha and Guha, 1939). Due to its high nutritive value the fish is recommended in the diet of the sick and the convalescents (Singh Kohli and Goswami, 1989). Being a lean fish it is very suitable for people for whom animal fats are undesirable (Rahman et al., 1982). The perch fish Anabas testudineus (Bloch) is one of the important fresh water fish of Bangladesh which is locally known as koi in different places of Bangladesh. Shingi and koi are commonly found in open waters (streams, lakes, floodplains and beels), paddy fields and swamps of Bangladesh and its preferred habitats are heavily-vegetated, stagnant waters. They are very hardy fish and can survive for a few hours out of the water due to the presence of accessory respiratory organs. Indiscriminate destructive practices have caused havoc to aquatic bio-diversity (Hussain and Mazid, 2001) in Bangladesh. International Union 
of Conservation of Nature (IUCN, 2000) enlisted $\mathrm{H}$. fossilis and A. testudineus in the "not threatened" category in Bangladesh. The native species are threatened now due to poorly planned water management policy for irrigation, over exploitation, illegal fishing and various ecological changes in its natural habitat (Chakraborty, 2010). Considering the importance of these species form the nutritional, economic and biodiversity point of view, appropriate culture technologies for $\mathrm{H}$. fossilis and A. testudineus are needed to meet the dietary demand and ultimately more of these tasty fishes will be available for the rural people of Bangladesh. For large scale production of these fishes, comprehensive information on culture technologies is required.

Therefore, the present study was conducted to find the maximum growth, yield and economic performance of shingi and genetically improved koi in various culture systems. The present experiment was also done to expand a practical and economically viable methodologies for mass production of these two species under controlled grow out culture practices. The polyculture technology of shingi and koi, and monoculture technology of koi can help to meet the dietary needs and improve the socio-economic status of the people of Bangladesh.

\section{Materials and Methods}

\section{Study area and experimental design}

The research was carried out at the private rearing ponds of three Fish Farms in Sadar, Gouripur and Gaffargaon Upazilla of Mymensingh district, Bangladesh. Foyaz Uddin Farm, Gouripur and Nazrul Islam Shabajpur, Sadar, Mymensingh was designated as treatment $\mathrm{T}_{1}$ and $\mathrm{T}_{2}$ for polyculture, and Babul Fish Farm, Basutia and Rubel Fish farm, Doulatpur, Gaffargaon was designated as treatment $T_{3}$ and $T_{4}$ for monoculture with three replicates each.
The experiment was conducted for a period of 100 days for koi and 120 days for shingi from May to August, 2010 in 12 ponds. The ponds were rectangular with an area of $0.30 \pm 0.11$ ha and an average depth of $1.10 \pm 0.12 \mathrm{~m}$. The growth performance of $\mathrm{H}$. fossilis and $\mathrm{A}$. testudineus was evaluated under four treatments and was replicated thrice and the pond dyke was covered with netting.

\section{Pond preparation and fertilization}

The ponds, with well-designed inlet and outlet system, were drained, cleared of aquatic vegetation and exposed to sunlight. After drying, lime $\left(\mathrm{CaCO}_{3}, 250 \mathrm{~kg} \mathrm{ha}^{-1}\right)$ was spread over the pond bottom. All the ponds were filled with ground water. Six days subsequent to liming, the ponds were fertilized with organic manure (cow dung @ 6,175 kg ha-1). Lime application (50 kg ha $^{-1}$ ) was maintained fortnightly to control water quality in all the treatments.

\section{Stocking of fingerlings}

Treatment $T_{1}$ and $T_{2}$ were stocked with shingi and $F_{2}$ population of (hormone 17 $\alpha$ methyltestosterone treated) koi. Treatment $T_{3}$ was stocked with only shingi and treatment $\mathrm{T}_{4}$ was stocked with only $F_{2}$ population of koi (Table 1). Stocking density was planned as shown in Table 1 . The fingerlings of shingi were stocked 15 days before stocking koi. The experimental ponds were stocked with shingi and koi with an initial length of $3.05 \pm 0.01 \mathrm{~cm}$ and weight of $2.54 \pm 0.11 \mathrm{~g}$, and $0.75 \pm 0.01 \mathrm{~cm}$ and $0.50 \pm 0.02 \mathrm{~g}$, respectively. The same stocking density of 0.247 million ha ${ }^{-1}$ was maintained in treatments $T_{1} T_{3}$ and $\mathrm{T}_{4}$. while stocking density of 0.3705 million ha $^{-1}$ was maintained in treatments $\mathrm{T}_{2}$. Culture period of shingi was recorded 120 days in treatment $T_{1}, T_{2}$ and $T_{3}$ and Culture period of Koi was recorded 100 days in treatment $T_{1}, T_{2}$ and $T_{4}$.

Table 1. Details of species combination and stocking density (individual ha-1) of four treatments

\begin{tabular}{cccccc}
\hline \multirow{2}{*}{ Sl. No. } & Name of the species & \multicolumn{4}{c}{ Stocking densities treatment wise ha- ${ }^{-1}$} \\
\cline { 3 - 6 } & & $\mathrm{T}_{1}$ & $\mathrm{~T}_{2}$ & $\mathrm{~T}_{3}$ & $\mathrm{~T}_{4}$ \\
\hline 1. & Heteropneustes fossilis & 74,100 & $1,23,500$ & $2,47,000$ & - \\
2. & Anabas testudineus & $1,72,900$ & $2,47,000$ & - & $2,47,000$ \\
\hline & Total & $2,47,000$ & $3,70,500$ & $2,47,000$ & $2,47,000$ \\
\hline
\end{tabular}

\section{Supplementary feeding}

Saudi Bangla and Mega feed were used in all treatments. Proximate composition of these commercial feeds was analysed according to AOAC (1995) method and nitrogen free extract (NFE) by subtraction (Castell and Tiews, 1980). Proximate composition (\% dry matter) of the supplementary floating Mega feed (crude protein, crude lipid, crude fibre, ash, moisture and nitrogen-free extract) of experimental feeds was $30.0 \%, 03.0 \%, 10.0 \%, 17.0 \%, 12.0 \%$ and $28.0 \%$ and sinking Saudi Bangla feed (crude protein, crude lipid, crude fiber, ash, moisture and nitrogen-free extract) of experimental feeds was $30.0 \%, 06.0 \%, 07.0 \%, 18.0 \%, 12.0 \%$ and $27.0 \%$, respectively. Feeds were supplied at the rate of (100-60)\% for the 1 st 15 days, (50-30)\% from 16 30 days, $(30-20) \%$ from $31-45$ days, $(20-10) \%$ 
from $46-60$ days, (10-8)\% from $61-75$ days , $6 \%$ from $76-90$ days and 5\% from 91-120 days twice daily in the morning and afternoon commencing from the first day of stocking. Daily ration was adjusted by estimating the standing crop once every fortnight by random sampling of the stock. Fifteen species of shingi and fifteen species of koi were sampled by using a seine and cast net.

\section{Water quality parameters}

Physico-chemical parameters of pond water were monitored fortnightly between 0900 and $1000 \mathrm{hr}$. Water temperature was recorded using a Celsius thermometer and transparency $(\mathrm{cm})$ was measured by using a Secchi disc of $20 \mathrm{~cm}$ diameter. Dissolved oxygen and $\mathrm{pH}$ were measured directly using a digital electronic oxygen meter (YSI, Model 58, USA) and an electronic pH meter (Jenway, Model 3020, UK). Total alkalinity was determined by titrimetric method (Clesceri et al., 1989).

\section{Water recycling}

Low-lift-pump was used to recycle surface water and shallow tube-well was used for adding under ground water in the pond (8000 L day $\left.{ }^{-1}\right)$. This method mitigated pollution from excretory product of individuals and maintained water quality suitable for the experimental fish and primary productivity.

\section{Estimation of growth, survival, production and feed utilisation}

Fishes were sampled by using seine and cast net. The length (cm) and weight ( $\mathrm{g}$ ) of individual fish was recorded separately with the help of a measuring scale and a portable sensitive balance. Weight of each species was measured separately to assess the health condition of fish and their growth. Twenty individuals of both $\mathrm{H}$. fossilis and A. testudineus species from each pond were sampled fortnightly until they attained marketable size. Growth in terms of weight, average daily growth (ADG), specific growth rate (SGR), food conversion ratio (FCR), and percentage survival and mean values $( \pm S D)$ for each parameter were computed. ADG and percentage survival were followed according to De Silva (1989). SGR was calculated according to Brown (1957) and Ricker (1979), and FCR was calculated according to Brown (1957) and Gangadhara et al. (1997). The marketable size koi and shingi were harvested after 100 and 120 days, respectively by repeated netting, followed by draining or drying the ponds. The number of individuals were counted and weighed. Survival percentage and production (individuals ha-1) of fingerlings were then calculated and compared among the treatments.

\section{Analysis of experimental data}

The data were analysed through one way analysis of variance (ANOVA) using MSTAT followed by Duncan's New Multiple Range test to find out whether there was any significant difference among treatment means (Duncan, 1955; Zar, 1984). The results were calculated and expressed as mean \pm SD. A simple cost-benefit analysis was done to estimate the net benefits from different treatments.

\section{Results}

\section{Water qua lity parameters}

Mean levels of physico-chemical parameters over the 120 days culture of $\mathrm{H}$. fossilis and $\mathrm{A}$. testudineus are presented in Table 2. The mean water temperature, $\mathrm{pH}$ and dissolved oxygen in treatments $T_{1}, T_{2}, T_{3}$ and $T_{4}$ were not significantly $(\mathrm{P}>0.05)$ different during the study period. Mean Secchi disk transparency and total alkalinity differed significantly $(\mathrm{P}<0.05)$ among different treatments. Despite these variations, water quality parameters in all the experimental treatments were within the normal range for fish culture.

Table 2. Physico-chemical parameters of experimental ponds under four treatments

\begin{tabular}{|c|c|c|c|c|}
\hline Parameters & $\begin{array}{c}\text { Treatment } \\
\mathrm{T}_{1}\end{array}$ & $\begin{array}{c}\text { Treatment } \\
\mathrm{T}_{2}\end{array}$ & $\begin{array}{c}\text { Treatment } \\
\mathrm{T}_{3}\end{array}$ & $\begin{array}{c}\text { Treatment } \\
\mathrm{T}_{4}\end{array}$ \\
\hline Temperature $\left({ }^{\circ} \mathrm{C}\right)$ & $\begin{array}{l}25.98 \pm 4.21 \\
(14.18-32.40)\end{array}$ & $\begin{array}{l}25.94 \pm 7.06 \\
(14.15-32.40)\end{array}$ & $\begin{array}{l}25.81 \pm 7.24 \\
(14.20-32.40)\end{array}$ & $\begin{array}{l}25.92 \pm 5.20 \\
(14.85-32.30)\end{array}$ \\
\hline Transparency (cm) & $\begin{array}{l}28.48 \pm 2.19 c \\
(23.80-39.50)\end{array}$ & $\begin{array}{l}30.30 \pm 3.64 \mathrm{~b} \\
(24.40-41.40)\end{array}$ & $\begin{array}{l}36.24 \pm 4.16^{\mathrm{a}} \\
(24.10-45.20)\end{array}$ & $\begin{array}{l}25.54 \pm 3.06^{d} \\
(22.10-33.40)\end{array}$ \\
\hline $\mathrm{pH}$ & $\begin{array}{l}8.12 \pm 0.30 \\
(7.70-8.50)\end{array}$ & $\begin{array}{l}8.08 \pm 0.33 \\
(7.80-8.60)\end{array}$ & $\begin{array}{l}8.17 \pm 0.31 \\
(7.70-8.55)\end{array}$ & $\begin{array}{l}8.20 \pm 0.30 \\
(7.60-8.60)\end{array}$ \\
\hline $\begin{array}{l}\text { Dissolved oxygen } \\
\left(\mathrm{mg} \mathrm{L}^{-1}\right)\end{array}$ & $\begin{array}{l}4.72 \pm 0.66 \\
(3.80-6.12)\end{array}$ & $\begin{array}{l}4.34 \pm 0.70 \\
(3.50-6.10)\end{array}$ & $\begin{array}{l}4.05 \pm 0.88 \\
(3.20-5.43)\end{array}$ & $\begin{array}{l}4.40 \pm 0.68 \\
(3.20-5.83)\end{array}$ \\
\hline $\begin{array}{l}\text { Total alkalinity } \\
\left(\mathrm{mg} \mathrm{L}^{-1}\right)\end{array}$ & $\begin{array}{l}160.60 \pm 6.24 \mathrm{a} \\
(148.40-174.20)\end{array}$ & $\begin{array}{l}153.23 \pm 16.69 d \\
(150.60-188.20)\end{array}$ & $\begin{array}{l}155.81 \pm 8.85 c \\
(146.50-181.40)\end{array}$ & $\begin{array}{l}156.43 \pm 7.80 \mathrm{~b} \\
(146.20-171.40)\end{array}$ \\
\hline
\end{tabular}

Figures with different superscripts in the same row varied significantly $(\mathrm{P}<0.05)$.

Figures in the parenthesis indicaterange. 


\section{Growth and production of fish}

The results of growth and production of fishes in terms of gain in weight in the four treatments are presented in Table 3. The results showed that there was significant difference in growth variation in each treatment and continued until the final harvest.

Table 3. Survival and production of $\mathrm{H}$. fossilis and A. testudineus species as obtained under four treatments during 120 and 100 days study

\begin{tabular}{|c|c|c|c|c|c|}
\hline \multirow[t]{2}{*}{ Parameters } & \multirow[t]{2}{*}{ Fish species } & \multicolumn{4}{|c|}{ Treatments } \\
\hline & & $\mathrm{T}_{1}$ & $\mathrm{~T}_{2}$ & $\mathrm{~T}_{3}$ & $\mathrm{~T}_{4}$ \\
\hline \multirow[t]{2}{*}{ Initial length $(\mathrm{cm})$} & H. fossilis & $3.05 \pm 0.01$ & $3.05 \pm 0.01$ & $3.05 \pm 0.01$ & - \\
\hline & A. testudineus & $0.75 \pm 0.01$ & $0.75 \pm 0.01$ & - & $0.75 \pm 0.01$ \\
\hline \multirow[t]{2}{*}{ Final length (cm) } & H. fossilis & $18.02 \pm 3.42^{\mathrm{a}}$ & $12.88 \pm 3.86^{b}$ & $18.17 \pm 3.88^{a}$ & - \\
\hline & A. testudineus & $15.71+2.40^{a}$ & $10.02 \pm 3.11^{b}$ & - & $15.88 \pm 2.61^{\mathrm{a}}$ \\
\hline \multirow[t]{2}{*}{ Net length (cm) } & H. fossilis & $14.97 \pm 3.02^{\mathrm{a}}$ & $9.83 \pm 3.66^{\mathrm{b}}$ & $15.12 \pm 3.38^{a}$ & - \\
\hline & A. testudineus & $14.96 \pm 2.36^{\mathrm{a}}$ & $9.27 \pm 3.01^{\mathrm{b}}$ & - & $15.13 \pm 2.41^{\mathrm{a}}$ \\
\hline \multirow[t]{2}{*}{ Initial weight (g) } & H. fossilis & $2.54 \pm 0.08$ & $2.54 \pm 0.08$ & $2.54 \pm 0.08$ & - \\
\hline & A. testudineus & $0.50 \pm 0.01$ & $0.50 \pm 0.01$ & - & $0.50 \pm 0.01$ \\
\hline \multirow[t]{2}{*}{ Final weight (g) } & H. fossilis & $50.14 \pm 3.22^{a}$ & $30.24 \pm 3.91^{\mathrm{c}}$ & $46.44 \pm 3.11^{b}$ & - \\
\hline & A. testudineus & $98.84 \pm 3.02^{\mathrm{a}}$ & $56.62 \pm 3.66^{b}$ & - & $98.92 \pm 3.82^{\mathrm{a}}$ \\
\hline \multirow[t]{2}{*}{ Net weight gain(g) } & H. fossilis & $47.60 \pm 3.11^{a}$ & $27.70 \pm 3.44^{c}$ & $43.90 \pm 3.05^{b}$ & - \\
\hline & A. testudineus & $98.34 \pm 3.01^{\mathrm{a}}$ & $56.12 \pm 3.32^{\mathrm{b}}$ & - & $98.42 \pm 3.08^{a}$ \\
\hline \multirow{4}{*}{$\begin{array}{l}\text { Average daily gain } \\
\text { (g) } \\
\text { SGR } \\
\left(\% \text { bw. day }{ }^{1}\right)\end{array}$} & H. fossilis & $0.40 \pm 0.01^{\mathrm{a}}$ & $0.23 \pm 0.01^{c}$ & $0.37 \pm 0.03^{b}$ & - \\
\hline & A. testudineus & $0.98 \pm 0.04^{a}$ & $0.56 \pm 0.02^{b}$ & - & $0.98 \pm 0.02^{\mathrm{a}}$ \\
\hline & H. fossilis & $3.14 \pm 0.04^{\mathrm{a}}$ & $2.63 \pm 0.03^{c}$ & $3.06 \pm 0.02^{b}$ & - \\
\hline & A. testudineus & $5.29 \pm 0.02^{\mathrm{a}}$ & $4.73 \pm 0.04^{\mathrm{b}}$ & - & $5.29 \pm 0.02^{\mathrm{a}}$ \\
\hline FCR & $\begin{array}{l}\text { H. fossilis } \\
\text { A. testudineus }\end{array}$ & $2.0 \pm 0.04^{c}$ & $2.8 \pm 0.06^{\mathrm{a}}$ & $2.6 \pm 0.04^{b}$ & $1.9 \pm 0.04^{\mathrm{d}}$ \\
\hline Species wise & H. fossilis & $87.08 \pm 2.51^{b}$ & $64.70 \pm 4.88^{c}$ & $87.55 \pm 2.02^{\mathrm{a}}$ & - \\
\hline survival rate (\%) & A. testudineus & $90.55 \pm 2.24^{\mathrm{a}}$ & $70.77 \pm 3.41^{b}$ & - & $90.76 \pm 2.07 \mathrm{a}$ \\
\hline $\begin{array}{l}\text { Average survival } \\
\text { rate(\%) }\end{array}$ & $\begin{array}{l}\text { H. fossilis } \\
\text { A. testudineus }\end{array}$ & $88.82 \pm 2.45^{b}$ & $67.74 \pm 4.29^{\mathrm{d}}$ & $87.55 \pm 2.02^{\mathrm{c}}$ & $90.76 \pm 2.07^{a}$ \\
\hline \multirow[t]{2}{*}{$\begin{array}{l}\text { Species wise } \\
\text { production }\end{array}$} & $\begin{array}{l}\text { H. fossilis } \\
\left(\text { kgha }^{-1} \text { day }^{120}\right)\end{array}$ & $3328.50 \pm 5.66^{b}$ & $2416.30 \pm 6.42^{c}$ & $10337.36 \pm 5.44^{\mathrm{a}}$ & - \\
\hline & $\begin{array}{l}\text { A. testudineus } \\
\left(\text { kgha- }^{-1} \text { day }^{-100}\right)\end{array}$ & $15474.08 \pm 6.14^{b}$ & $9897.23 \pm 6.88^{c}$ & - & $22175.60 \pm 7.35^{a}$ \\
\hline $\begin{array}{l}\text { Total production } \\
\left(\mathrm{kg} \mathrm{ha}^{-1)}\right.\end{array}$ & & $18802.58 \pm 111.06^{b}$ & $12388.25 \pm 115.22^{c}$ & $10042.56 \pm 5.44^{d}$ & $22175.60 \pm 7.35^{a}$ \\
\hline
\end{tabular}

Values in the same row having the same superscript are not significantly different ( $P>0.05$ ). Shingi and Koi fish were harvested after day ${ }^{120}$ and day ${ }^{100}$

\section{H. fossilis (Shingi)}

During the investigation, mean final length and weight of $\mathrm{H}$. fossilis was recorded as $14.97 \pm 3.02$ $\mathrm{cm}, 9.83 \pm 3.66 \mathrm{~cm}$ and $15.12 \pm 3.38 \mathrm{~cm}$; and $50.14 \pm 3.22 \mathrm{~g}, 30.24 \pm 3.91 \mathrm{~g}$ and $46.44 \pm 3.11 \mathrm{~g}$ in treatments $T_{1}, T_{2}$ and $T_{3}$, respectively (Fig. 1 and 2 ). The increase in weight of $H$. fossilis was the highest in $T_{1}$ followed by $T_{3}$ and $T_{2}$, respectively. The initial weight of fingerlings, stocked in all the ponds did not vary significantly $(\mathrm{P}<0.05)$. The fish in $T_{1}$ treatment showed the highest gain in weight as compared to the polyculture treatment $\mathrm{T}_{2}$ and monoculture treatment $\mathrm{T}_{3}$. However, the mean final weight of individuals in different treatments were significantly different $(\mathrm{P}<0.05)$. SGR in treatment $T_{1}$ was significantly higher $(\mathrm{P}<0.05)$ than in $\mathrm{T}_{3}$ and $\mathrm{T}_{2}$. The highest survival rate was also observed in $\mathrm{T}_{3}$ and the lowest in $\mathrm{T}_{2}$. There was a significant variation $(\mathrm{P}<0.05)$ in the survival rate of $\mathrm{H}$. fossilis among different treatments. The mean productions of $\mathrm{H}$. fossilis were $\quad 3,328.5 \pm 5.66, \quad 2,416.30 \pm 6.42$ and $10,337.36 \pm 5.44 \mathrm{~kg} \mathrm{ha}^{-1}$ day ${ }^{-120}$ in treatments $\mathrm{T}_{1}, \mathrm{~T}_{2}$ and $T_{3}$, respectively. The total production of $H$. fossilis differed significantly $(\mathrm{P}<0.05)$ among the treatments (Table 3). Production was higher in monoculture treatment $\mathrm{T}_{3}$ and lower in polyculture treatments $T_{1}$ and $T_{2}$. 


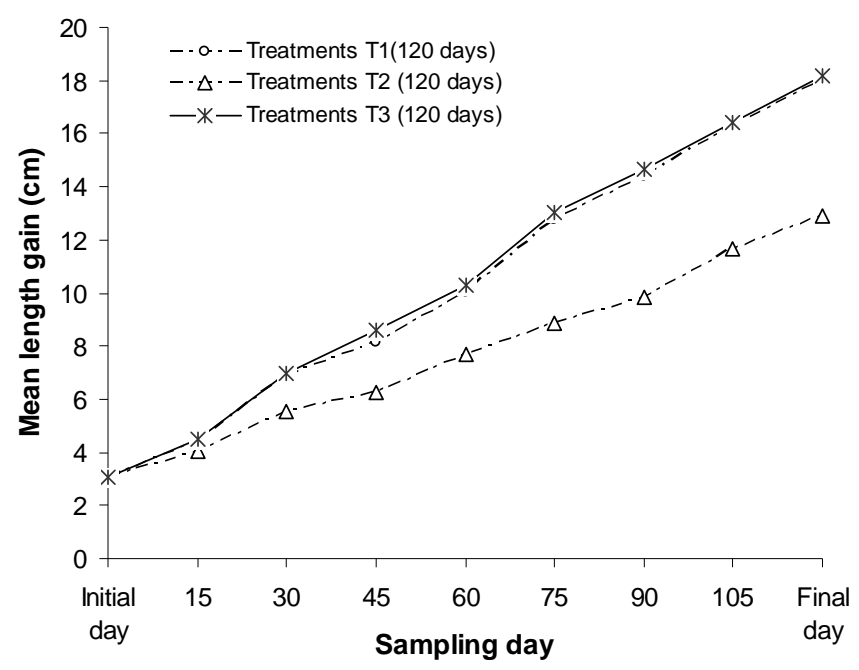

Fig.1. Fortnightly mean length $(\mathrm{cm})$ gain of shingi under different treatments over a period of 120 days

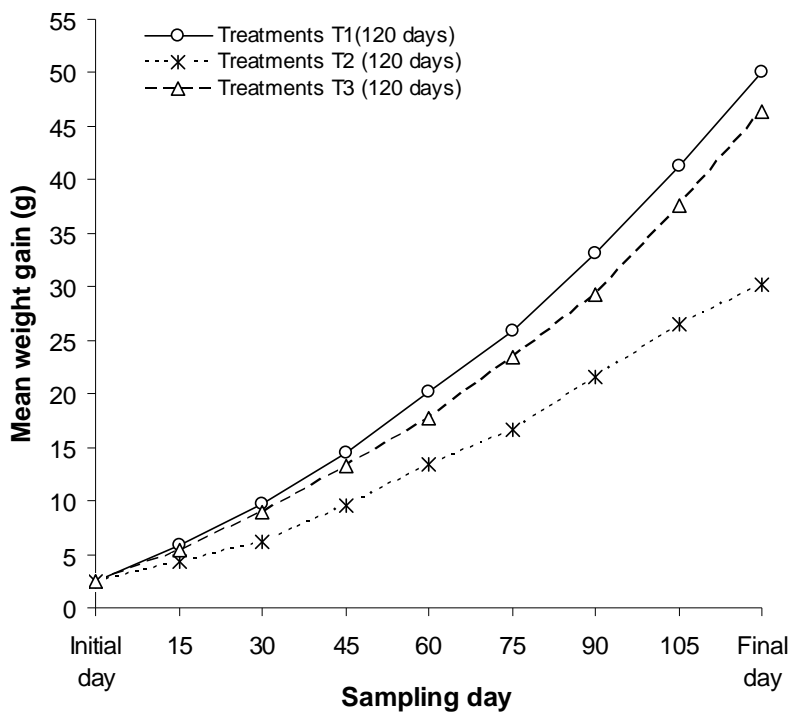

Fig.2. Fortnightly mean weight (g) gain of shingi under different treatments over a period of 120 days

\section{A. testudineus (Koi)}

During the experimental period, the final mean length and weight of A. testudineus was found to be $14.96 \pm 2.36 \mathrm{~cm}, 9.27 \pm 3.01 \mathrm{~cm}$ and $15.13 \pm 2.41$ $\mathrm{cm}$, and $98.34 \pm 3.02 \mathrm{~g}, 56.62 \pm 3.66 \mathrm{~g}$ and $98.92 \pm 3.82 \mathrm{~g}$ in treatments $\mathrm{T}_{1}, \mathrm{~T}_{2}$, and $\mathrm{T}_{4}$ respectively (Fig. 3 and 4). Growth and production parameters of $\mathrm{A}$. testudineus are shown in Table 3. The initial weight of fingerling, stocked in all treatments did not differ significantly. The fish in monoculture treatment $\mathrm{T}_{4}$ showed the highest gain in weight as compared to the polyculture treatments $T_{1}$ and $T_{2}$. However, the mean final weight of $\mathrm{A}$. testudineus in treatment $T_{1}$ and $T_{4}$ were not significantly different $(\mathrm{P}>0.05)$. SGR in polyculture treatment $\mathrm{T}_{1}$ and monoculture treatment $\mathrm{T}_{4}$ was the same but significantly higher than in another polyculture treatment $T_{2}(\mathrm{P}<0.05)$. The highest survival rate was also observed in monoculture treatment $\mathrm{T}_{4}$ and the lowest in polyculture treatment $T_{2}$. There was a significant variation $(\mathrm{P}<0.05)$ in the survival rate of $\mathrm{A}$. testudineus individuals among different treatments. The mean productions of $\mathrm{A}$. testudineus were $15,474.08 \pm 6.14, \quad 9,897.23 \pm 6.88 \quad$ and $22,175.6 \pm 7.35 \mathrm{~kg} \mathrm{ha}^{-1}$ day-100 in treatments $\mathrm{T}_{1}, \mathrm{~T}_{2}$ and $\mathrm{T}_{4}$, respectively. Production was higher in monoculture treatment $\mathrm{T}_{4}$ and lowest in polyculture treatment $T_{2}$. The growth rate was the same in treatment $\mathrm{T}_{1}$ and $\mathrm{T}_{4}$ but lower in treatment $\mathrm{T}_{3}$. The production of $\mathrm{A}$. testudineus also differed significantly $(\mathrm{P}<0.05)$ among the three treatments. 


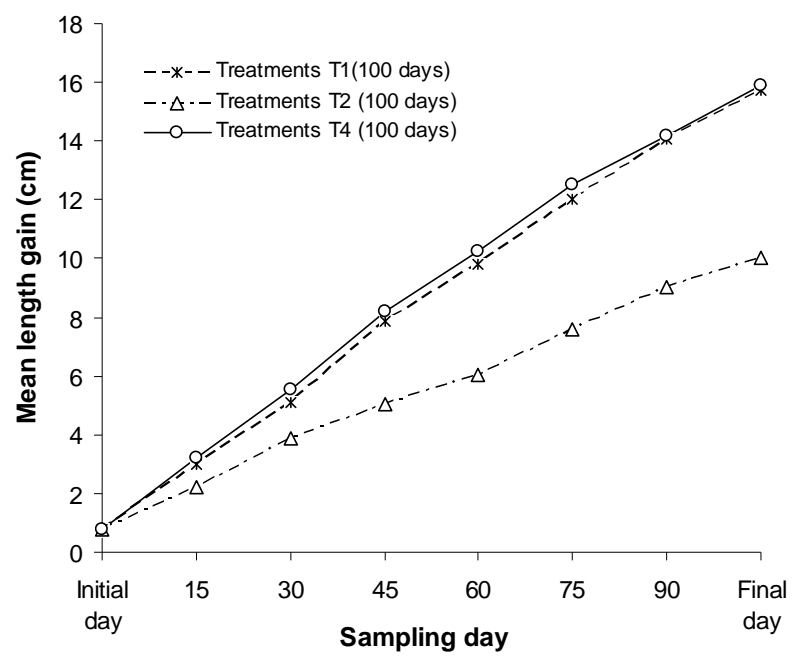

Fig. 3. Fortnightly mean length $(\mathrm{cm})$ gain of koi under different treatments over a period of 100 days

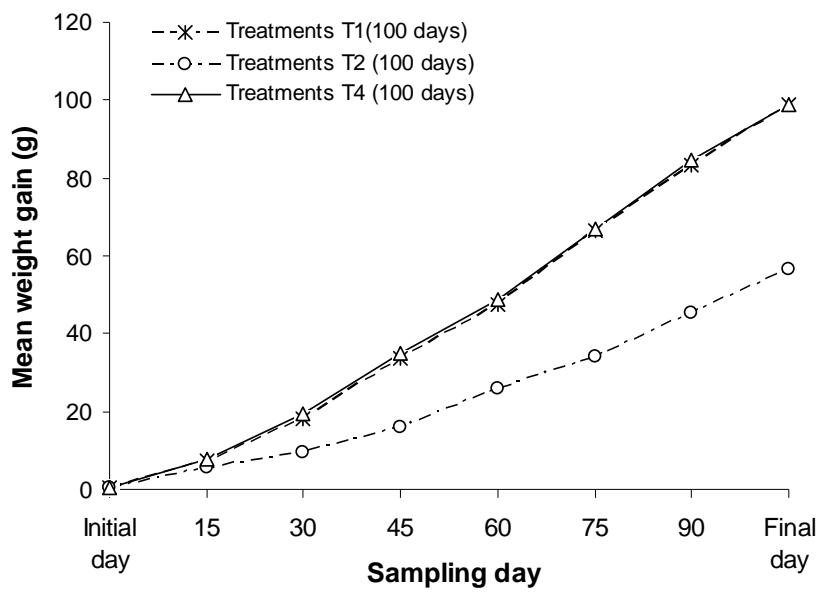

Fig. 4. Fortnightly mean weight (g) gain of koi under different treatments over a period of 100 days

\section{Total production}

In the study, FCR was significantly lower in monoculture treatment $\mathrm{T}_{4}$ than in polyculture treatment $\mathrm{T}_{1}$ followed by the monoculture treatment $\mathrm{T}_{3}$ and polyculture treatment $\mathrm{T}_{2}$. Best FCR was recorded in monoculture treatment $\mathrm{T}_{4}$. Total net production of fish as recorded in treatments $\quad \mathrm{T}_{1}, \quad \mathrm{~T}_{2}, \quad \mathrm{~T}_{3}$ and $\mathrm{T}_{4}$ were 18,802.58 $\pm 111.06, \quad 12,388.25 \pm 115.22$, $10,042.56 \pm 5.44$ and $22,175.6 \pm 7.35$ kg ha-1, respectively. The production of fish was higher in monoculture treatment $\mathrm{T}_{4}$, where only $\mathrm{F}_{2}$ population of A. testudineus was stocked at 2, 47,000 ha- ${ }^{-1}$ and lowest production was recoded in monoculture treatment $\mathrm{T}_{3}$, where only $\mathrm{H}$. fossilis was stocked at 2, 47,000 ha-1. Second highest production was recorded in polyculture treatment $T_{1}$, where $H$. fossilis and $A$. testudineus were stocked respectively at 74,100 and $1,72,900$ no. ha $^{-1}$ and an intermediate production was obtained in polyculture treatment $\mathrm{T}_{2}$, where $\mathrm{H}$. fossilis and A. testudineus were stocked respectively at
1,23,500 and 2,47,00 ha-1. The production levels in all treatment differed significantly $(\mathrm{P}<0.05)$.

\section{Economic analysis}

A simple cost-benefit analysis was performed to estimate the amount of profit that had been generated from these four types of culture operations. The results of the analysis are shown in Table 4. The cost of production in treatment $\mathrm{T}_{2}$ was consistently significantly higher than those of treatments $T_{4}, T_{1}$ and $T_{3}$. Highest net benefit was obtained in treatment $\mathrm{T}_{1}$ (BDT. $17,65,769)$ followed by $\mathrm{T}_{4}$ (BDT. 16,29,406), $\mathrm{T}_{3}$ (BDT. 15,83,990) and $\mathrm{T}_{2}$ (BDT. 6,691). Second and third net return benefit was found to be in the monoculture treatments $\mathrm{T}_{4}$ and $\mathrm{T}_{3}$. Treatment $\mathrm{T}_{2}$ appeared to give poor net return levels and differed significantly $(\mathrm{P}<0.05)$ from $\mathrm{T}_{1}, \mathrm{~T}_{3}$ and $\mathrm{T}_{4}$. Although the higher production was recorded in monoculture of A. testudineus (treatment $\mathrm{T}_{4}$ ), the higher net benefit was found in polyculture treatment $T_{1}$ due to reason of high market price of $\mathrm{H}$. fossilis. 
Table 4. Cost and return of fish production under a polyculture management of $\mathrm{H}$. fossilis and $\mathrm{A}$. testudineus over a period of 120 and 100 days

\begin{tabular}{|c|c|c|c|c|c|}
\hline \multirow[t]{2}{*}{ Item } & \multicolumn{4}{|c|}{ Amount BDT ha $^{-1}$ day $^{-120}$} & \multirow[t]{2}{*}{ Remarks } \\
\hline & $\begin{array}{c}\text { Treatment } \\
\mathrm{T}_{1}(\mathrm{Tk})\end{array}$ & $\begin{array}{c}\text { Treatment } \\
\mathrm{T}_{2}(\mathrm{Tk})\end{array}$ & $\begin{array}{c}\text { Treatment } \\
\mathrm{T}_{3}(\mathrm{Tk})\end{array}$ & $\begin{array}{c}\text { Treatment } \\
\mathrm{T}_{4}(\mathrm{Tk})\end{array}$ & \\
\hline Total return (TR) & $3453527 a$ & $1813585^{d}$ & $3213619 c$ & $3326340^{\mathrm{b}}$ & $\begin{array}{l}\text { Price related with size } \\
\text { and weight }\end{array}$ \\
\hline $\begin{array}{l}\text { a. Variable cost: } \\
\text { 1. Price of fingerlings } \\
\text { 2. Feed }\end{array}$ & $\begin{array}{c}321100 \\
1024912\end{array}$ & $\begin{array}{l}494000 \\
961208\end{array}$ & $\begin{array}{l}494000 \\
806286\end{array}$ & $\begin{array}{l}247000 \\
1100710\end{array}$ & (BDT $25.00 \mathrm{~kg}^{-1}$ ) \\
\hline $\begin{array}{l}\text { 3. Fertilizer } \\
\text { 4. Human labour cost } \\
\text { 5. Chemicals } \\
\text { 6. Miscellaneous } \\
\text { Total Variable cost } \\
\text { (TVC) }\end{array}$ & $\begin{array}{c}10369 \\
48000 \\
12470 \\
100250 \\
1517101\end{array}$ & $\begin{array}{c}10369 \\
48000 \\
11580 \\
100250 \\
1625407\end{array}$ & $\begin{array}{c}10369 \\
48000 \\
12870 \\
100250 \\
1471775\end{array}$ & $\begin{array}{c}10369 \\
48000 \\
13750 \\
100250 \\
1520079\end{array}$ & $\begin{array}{l}\left(\text { BDT } 9.00 \mathrm{~kg}^{-1}\right) \\
\left(\mathrm{BDT} 200.00 \text { day }^{-1}\right)\end{array}$ \\
\hline $\begin{array}{l}\text { b. Fixed cost: } \\
\text { 1. Pond rental value } \\
\left(\text { day }^{-120}\right)\end{array}$ & 18947 & 18947 & 18947 & 18947 & $\begin{array}{l}\text { BDT } 200.00 \text { dec. }^{-1} \\
\text { according to local rate, } \\
\text { Mymensingh }\end{array}$ \\
\hline $\begin{array}{l}\text { Interest of operating } \\
\text { capital }\end{array}$ & 151710 & 162540 & 138907 & 157907 & $\begin{array}{l}10 \% \text { interest according } \\
\text { to BKB, Bangladesh }\end{array}$ \\
\hline Total fixed cost (TFC) & 170657 & 181487 & 157854 & 176854 & \\
\hline $\begin{array}{l}\text { Total cost } \\
\text { (TC=TVC+TFC) }\end{array}$ & $1687758^{b}$ & $1806894^{c}$ & $1629629 \mathrm{~d}$ & $1696933^{a}$ & \\
\hline $\begin{array}{l}\text { Gross margin } \\
\text { (GM=TR-TVC) }\end{array}$ & $1936426^{a}$ & $188178^{b}$ & $1741844^{\mathrm{d}}$ & $1747261^{c}$ & \\
\hline Net return (TR-TC) & 1765769a & $6691^{\mathrm{d}}$ & $1583990^{c}$ & 1629409b & \\
\hline
\end{tabular}

Values with different superscripts in the same row varied significantly $(\mathrm{P}<0.05)$.

1.00US\$ =75.00 BDT (Bangladeshi Taka).

$\mathrm{BKB}=$ Bangladesh Krishi (Agricultural) Bank.

Sale price of shingi and koi in treatment T1 was BDT $350.00 \mathrm{~kg}^{1}$ and $150.00 \mathrm{~kg}^{1}$, and in T2 BDT $300.00 \mathrm{~kg}^{1}$ and $100.00 \mathrm{~kg}^{-1}$, respectively, in $\mathrm{T}_{3}$ (only shingi) BDT $320.00 \mathrm{~kg}^{-1}$ and in $\mathrm{T}_{4}$ (only koi) BDT $150.00 \mathrm{~kg}^{-1}$.

\section{Discussion}

Growth, feed efficacy and feed consumption of fish are normally governed by a few environmental factors (Brett, 1979). The temperature, water transparency, $\mathrm{pH}$, dissolved oxygen and total alkalinity of the experimental ponds were within the acceptable range for fish culture that agrees well with the findings of Boyd (1979), Wahab et al. (1994) and Chakraborty et al. (2005). Higher total alkalinity level in the water of the experimental ponds might be due to higher amount of lime applied during pond preparation and frequent liming every 15 days interval during the study period (Boyd, 1982; J hingran, 1991).

In this experiment, similar supplementary feeds are supplied for the growth of $\mathrm{H}$. fossilis and $\mathrm{A}$. testudineus, as explained by Haque and Barua (1989). The crude protein levels $(30.0 \%$ dry weight) in supplementary feeds were very near the dietary protein of $31 \%$ for the optimal growth of Labeo rohita (De Silva and Gunasekera, 1991). Growth in terms of weight, weight gain and SGR of individuals of $\mathrm{H}$. fossilis and A. testudineus was significantly higher in $\mathrm{T}_{1}$ (polyculture), where the combined stocking density of the two species was the same with the stocking density of $\mathrm{H}$. fossilis monoculture in $\mathrm{T}_{3}$ as well as the stocking density of $\mathrm{A}$. testudineus monoculture in $\mathrm{T}_{4}$, although the same food was supplied in all the treatments at an equal ratio. The low growth rate of $\mathrm{H}$. fossilis and A. testudineus in treatment $T_{2}$ appeared to be related with higher densities and increased competition for natural food and space. The inverse relationship between the stocking density and the grouth rate is a space limiting effect on the population (Johnson, 1965).

During the experimental period, ecological factors, pond preparation and good management practices, feed quality, healthy fingerlings, and stocking rate influenced the high performance in the survival rate of $\mathrm{H}$. fossilis and A. testudineus (Choudhury et al., 1978). Chiu et al. (1989) and De Silva and Davy (1992) stated that digestibility plays an important role in lowering the FCR value by efficient utilization of food. The FCR value in monoculture treatment $\mathrm{T}_{4}$ was significantly lower than those of polyculture treatments $T_{1}$ and $T_{2}$, and monoculture treatment $\mathrm{T}_{3}$. Digestibility, in turn, depends on daily feeding rate, frequency of feeding, and type of 
food used. There was a general decrease in FCR for the population of treatment $\mathrm{T}_{4}$ than that of the treatment $T_{1}, T_{3}$ and $T_{2}$ which is supported by Pechsiri and Yakupitiyage (2005). The FCR values of different treatments were acceptable and indicated better food utilization, which is agreed by Das and Ray (1989), Reddy and Katro (1979) and Islam (2002). Significantly, higher survival was recorded in monoculture treatment $\mathrm{T}_{4}$ and polyculture treatment $T_{1}$, where, the stocking density was lower than treatment $\mathrm{T}_{2}$. The reason for reduced survival rate in treatment $T_{2}$ might be due to higher stocking density of individuals as well as competition for natural food and space in the water area of pond which is supported by Tripathi et al. (1979), Haque et al. (1994) and Chakraborty et al. (2005).

In the present investigation, the amount of supplementary feeds given in different treatments was based on the number of fingerlings stocked and amount of feed provided per individual was kept at the same level. In this experiment, at higher stocking densities, presence of abundant food substances could produce a comparative interaction among the population causing a stressful situation (Houde, 1975). Hence, the observed poor growth at higher stocking densities could be due to space limiting effect, stressful situation caused by supplementary feed, some variations in environmental parameters and less availability of natural food. The results in the present experiment are very similar to the study of Ameen et al. (1984); Vijayakumar et al. (1998); Usmani et al. (2003) and Chakraborty et al. (2005).

In the present study, a significant higher production $\left(22,175.6 \pm 7.35 \mathrm{~kg} \mathrm{ha}^{-1}\right.$ day $\left.^{-100}\right)$ was recorded in treatment $\mathrm{T}_{4}$ than those of treatment $\mathrm{T}_{1}, \mathrm{~T}_{2}$ and $\mathrm{T}_{3}$, respectively. Despite this, consistently higher net benefits (BDT. 17,65,769 ha $^{-1}$ ) were obtained from treatment $T_{1}$ than those of treatment $T_{4}, T_{3}$ and $T_{2}$. The higher net benefit in treatment $T_{1}$ was obtained due to stocking of $H$. fossilis (high market value fish), although the second higher production was recorded in this treatment. The observation of higher net benefit is in agreement with those of Thakur and Das (1986), Munshi (1996), Vijayakumar et al. (1998), Noor Khan et al. (2003), Usmani et al. (2003) and Chakraborty et al. (2005). Overall, highest growth, survival, production and benefits were obtained from the monoculture treatment $\mathrm{T}_{4}$ and second higher growth, survival, production and highest benefit were recorded in polyculture treatment $T_{1}$ which is influenced by a well developed water recirculation method (Chakraborty and Mirza. 2008).

In the present investigation, the amount of supplementary feeds given in different treatments was based on the weight of fish stocked and amount of feed provided per individual was kept at the same level. Hence, the observed low growth, production and lowest benefit in treatment $\mathrm{T}_{2}$ could be due to higher stocking density, variations in environmental parameters. The results in the present experiment are very similar to those of Saha et al. (1988); Kohinoor et al. (1998); Hossain (2001) and Chakraborty and Azad (2008).

\section{Conclusion}

The survival, growth and production in polyculture and monoculture systems were inversely related to the stocking densities of fingerlings. Monoculture of A. testudineus as in treatment $\mathrm{T}_{4}$ and polyculture of $\mathrm{H}$. fossilis and $\mathrm{A}$. testudineus as in treatment $\mathrm{T}_{1}$ can be recommended to fish farmers to produce more protein food for the Bangladesh population. . This may also be helpful towards the protection of shingi from extinction as well as for the conservation of koi.

\section{Acknowledgements}

The author thanks private hatchery owners of Fish Farms who helped in conducting the experiments with financial support.

\section{References}

Ameen, M., Islam, K.R., Ahmed, K. and Mustafa. G. 1984. Indigenous small fish culture in mini ponds. Bangladesh J. Zool. 12: 1-10.

AOAC. 1995. Official methods of analysis of AOAC International, Vol. 2, 16th edition. (ed. W. Howritz), 1018 pp. Association of Analytical Communities, Washington, DC USA.

Boyd, C.E. 1979. Water quality in warm water fish ponds, Alabas Seed Agricultural Experiment Station, Auburn, Alabama, USA. $369 \mathrm{p}$.

Boyd, C.E. 1982. Water quality management for pond fish culture. Elsevier, The Netherlands. $318 \mathrm{p}$.

Brett, J.R. 1979. Environmental factors and growth. In: Environmental relations and behavior, Fish Physiology Vol. 6 (eds. W.S. Hoar, D.J. Randal and J.R. Brett). pp. 599677. Academic press, New York.

Brown, M.E. 1957. Experimental studies on growth. In: The physiology of fishes. Vol. I, (ed. M.E. Brown). pp. 36-400. Academic Press, New York.

Castell, J.D. and Tiews, K. (eds.). 1980. Report of the EIFAC, IUNS and ICES working group on the standardization of methodology in fish nutrition research, Hamburg, Federal Republic of Germany, 2123 March, 1979, EIFAC Tech. Paper. 26 p. 
Chakraborty, B.K. 2010. Status and position of aquatic biodiversity of four beels and its floodplain level of northern Bangladesh with a good practice of beel nurseries. In: Advances in environmental research. (ed. J. A. Daniels) Nova Science Publishers, New York, USA. 8: 121-164.

Chakraborty, B.K. and Azad, S.A. 2008. Rearing and nursing of Singi, Heteropneustes fossilis (Bloch) at different densities in earthen nursery ponds of Bangladesh. Bangladesh J. Life Sci. 20 (1): 131-141.

Chakraborty, B.K. and Mirza, M.J.A. 2008. Growth and yield performance of threatened Singi, Heteropneustes fossilis (Bloch) under semi intensive aquaculture. J. Fish. Soc., Taiwan. 35: 117-125.

Chakraborty, B.K., Miah, M.I., Mirza, M.J.A. and Habib, M.A.B. 2005. Growth, yield and returns to Puntius sarana (Hamilton) Sarpunti, in Bangladesh under semi intensive aquaculture. Asian Fish. Sci. 18: 307-322.

Chiu, Y.N., Das, I. and Ray, A.K. 1989. Growth performance of Indian major carps Labeo rohita (Ham.) on duckweed incorporate pelleted feed: a preliminary study. J. Inland Fish. 21: 1-6.

Choudhury, H., Rao, N.G.S., Saha, G.N., Rout, M. and Ranaujia, D.R. 1978. Record fish production through intensive fish culture in a farmer's pond. J. Inland Fish. 10: 19-27.

Clesceri, L.S., Greenberg, A.E. and Trussell, R.R. 1989. Standard methods of the examination of water and wastewater (17th edition.). American Public Health Association, American Water Works Association and Water Pollution Control Federation, 1015 Washington D. C., USA. pp. 475-481.

Das, I. and Ray, A.K. 1989. Growth performance of Indian major carps Labeo rohita (Ham.) on duckweed incorporate pelleted feed: a preliminary study. J. Inland Fish. 21: 1-6.

De Silva, S.S., 1989. Reducing feed costs in semiintensive aquaculture systems in the tropics. NAGA, ICLARM Quarterly. 12: 6-7.

De Silva, S.S. and Davy, F.B. 1992. Fish nutrition research system in Asia. Asian Fish. Sci. 5: 129-144.

De Silva, S.S. and Gunasekera, R.M. 1991. An evaluation of the growth of Indian and Chinese major carps in relation to the dietary protein content. Aquaculture. 92: 237-241.

Duncan, D.B. 1955. Multiple range and multiple F-testes. Biometrics. 11: 1-42.

Gangadhara, B., Nandeesha, M.C., Varghese, T.J. and Keshavanath, P. 1997. Effect of varying protein and lipid levels on the growth of Rohu, Labeo rohita. Asian Fish. Sci. 2: 139147.
Haque, M.M. and Barua, G. 1989. Rearing of shingi (Heteropneustes fosilis, Bloch) fry under laboratory condition-II. Feeding and growth of fry. Bangladesh J. Fish. 12: 67-72.

Haque, M.Z, Rahman, M.A. and Hossain, M.M. 1994. Studies on the effect of stocking densities on the growth and survival of mrigal (Cirrhinus mrigala) fry in rearing ponds. Bangladesh J. Zool. 21: 51-58.

Hossain, Q.Z 2001. Induced breeding of the fish Cirrhinus reba by pituitary gland extract and survival of spawn in nursery ponds. J . Asiatic Soc. 27: 205-213.

Houde, E.D. 1975. Effect of stocking density and food on survival, growth and yield of laboratory reared of sea Bream, Archosargus rhomboidales (L.) (Sparidae). J. Fish. Biol. 7: 115-127.

Hussain, M.G. and Mazid, M.A. 2001. Genetics improvement and conservation of carp species in Bangladesh. Bangladesh Fisheries Research Institute, Mymensingh. $56 \mathrm{p}$.

Islam, M.S. 2002. Evaluation of supplementary feeds for semi intensive pond culture of Mahaseer, Tor putitora (Hamilton). Aquaculture. 212: 263-276.

IUCN, Bangladesh. 2000. Red book of threatened fish of Bangladesh. The world conservation Union. Appendix 1, 61 p.

Jhingran, V.G. 1975. Aquaculture lecture, summer intensive fresh water fish culture, Cuttack organized by Central. Inland Fisheries Research Institute, Barracckpore (ICCR), West Bengal, India. $12 \mathrm{p}$.

Jhingran, V.G. 1991. Fish and fisheries of India, 3rd edition. Hindustan Publishing Corporation Delhi, India. $727 \mathrm{p}$.

Johnson, W.E. 1965. On mechanism of self regulation of population abundance in Oncorhynchus nerka. Mitteilung Internationale Vereinigung fuer Theoretische unde Amgewandte. 13: 66-87.

Kohinoor, A.H.M., Islam, M.L., Wahab, M.A. and Thilsted, S.H. 1998. Effect of mola (Amblypharyngodon mola, Hamilton) on the growth and production of carps in polyculture. Bangladesh J. Fish. 2: 119-126.

Munshi, J.S.D. 1996. Ecology of Heteropneustes fossilis, an air-breathing catfish of SouthEast Asia. Narendra Publishing House, Delhi. $174 \mathrm{p}$.

Noor Khan, M., Saiful Islam, A.K.M. and Hussain, M.G. 2003. Marginal analysis of culture of stinging catfish (Heteropneustes fossilis, Bloch) effect of different stocking densities in earthen ponds. Pakistan J. Biol. Sci. 6: 666-670.

Pechsiri, J. and Yakupitiyage, A. 2005. A comparative study of growth and feed utilization efficiency of sex-reversed diploid 
and triploid Nile tilapia, Oreochromis niloticus L. Aqua. Res. 36: 45-51.

Rahman, M.A., Gheyasuddin, H., Rasid, M.H. and Choudhury, M.F.Z. 1982. Proximate composition and native quality of freshwater Zeol fishes of Bangladesh. Bangladesh J. Fish. 25: 37-43.

Redddy, S.R. and Katro, S. 1979. Growth and conversion efficiency of air breathing catfish, Heteropneustes fossilis in relation to ration size. Aquaculture. 18: 35-50.

Ricker, W.E. 1979. Computation and interpretation of biological statistics of fish populations. Bull. Fish. Res. Board Canada. 191: 1-382.

Saha, K.C. and Guha, B.C. 1939. Nutritional investigation on Bengal fish. Indian J. Medical Res. 26: 921-927.

Saha, S.B., Gupta, M.V., Hossain, M.G. and Shah, M.S. 1988. Growth and survival of rohu (Labeo rohita) fry in rearing ponds at different stocking densities. Bangladesh J. Zool. 16: 119-126.

Singh Kohli, M.P. and Goswami, U.C. 1989. Studies on age and growth of an airbreathing catfish Heteropneustes fossilis (Bloch). J . Inland Fish. Soc. India. 21: 17-24.
Thakur, N.K. and P. Das, 1986. Synopsis of biological data on Singhi Heteropneustes fossilis (Bloch, 1974). Bull. No. 39, April 1986. Central Inland Fisheries Research Institute, Barrackpore, India, $32 \mathrm{pp}$.

Tripathi, S.D., Dutta, A., Sen Gupta, K.K and Pattra, S. 1979. High density rearing of rohu spawns in village ponds. In: Symposium of Inland Aquaculture (Abstracts). p.14. February 12-13, 1979. CIFRI. Barrack pore, India.

Usmani, N., J afrim, A.K. and Khan, M.A. 2003. Nutrient digestibility studies in Heteropneustes fossilis (Bloch), Clarias batrachus (Linnaeus) and C. gariepinus (Burchell). Aqua. Res. 34: 1365-2109.

Vijayakumar, C., Sridhar, S. and Haniffa, M.A. 1998. Low cost breeding and hatching techniques for the catfish, Heteropnuestes fossilius for small-scale farmers. NAGA. 21 (4): 15-17.

Wahab, M.A., Ahmed, Z.F., Haq, M.S. and Begum, M. 1994. Compatibility of silver carp in the poly culture of cyprinid fishes. ProgressiveAgriculture. 5: 221-227.

Zar, J.H. 1984. Biostatistics: Prentice-Hall, Inc. Englewood Cliffs, New J ersey, USA. 718 p. 